\title{
The impact of work on the health of nursing professionals*
}

\author{
O impacto do trabalho para a saúde do profissional de enfermagem \\ El impacto del trabajo en la salud del profesional enfermero
}

How to cite this article:

Pimenta CJL, Silva CRR, Bezerra TA, Costa TF, Oliveira JS, Costa KNFM. The impact of work on the health of nursing professionals. Rev Esc Enferm USP. 2020;54:e03584. doi: https://doi.org/10.1590/S1980-220X2018046103584

\section{Cláudia Jeane Lopes Pimenta ${ }^{1}$ \\ Cleane Rosa Ribeiro da Silva ${ }^{1}$ \\ iD Thaíse Alves Bezerra ${ }^{1}$ \\ (D) Tatiana Ferreira da Costa ${ }^{1}$ \\ (D) Jacira dos Santos Oliveira ${ }^{1}$ \\ (i) Kátia Neyla de Freitas Macedo Costa $^{1}$}

* Extracted from the dissertation: "Trabalho de enfermagem: comunicação, prazer e sofrimento", Universidade Federal da Paraíba, 2018.

${ }^{1}$ Universidade Federal da Paraíba,

João Pessoa, PB, Brazil.

\begin{abstract}
Objective: To evaluate the impact of work on nursing professionals' health Method: This is a cross-sectional and quantitative study conducted with nurses from a university hospital in João Pessoa, Paraíba, Brazil. Data were collected through interviews using an instrument to obtain sociodemographic data and health conditions and the Pleasure and Suffering Indicators at Work Scale (PSIWS). Results: There were 152 nurses who participated. The Experience of Pleasure and its domains were rated as satisfactory, while Suffering Factors and their domains were critically evaluated. Statistically significant associations were observed $(p \leq 0.05)$ between the indicators of pleasure and suffering and some health conditions, health problems and medication use. Conclusion: Satisfactory levels of pleasure were associated with better health conditions and critical levels of suffering were associated with worse health conditions.
\end{abstract}

\section{DESCRIPTORS}

Work; Nursing; Job Satisfaction; Occupational Health. 


\section{INTRODUCTION}

Work represents an important resource of the social system of human beings, since performing an activity makes the individual more integrated with the world, enables acquiring and constructing knowledge, strengthens autonomy and promotes skill development ${ }^{(1)}$. The expansion of the capitalist production mode and the rise of the globalization process caused significant changes in the financial market, resulting in alienation, individuality, precariousness of management models and the fragmentation of labor practice itself ${ }^{(2)}$.

Due to the stratification of this process, professionals could become just another component of a mechanized system which prioritizes production growth ${ }^{(3)}$. The organization of health services was also influenced by changes in the labor market. The demand for the provided care quality in nursing often without the necessary conditions for its performance, has led to an increase in occupational injuries, more frequently musculoskeletal disorders, anxiety disorders and depressive episodes ${ }^{(4)}$, which has repercussions on the determinants of the health-disease process in the form of high levels of stress, high levels of dissatisfaction and intention to leave the profession ${ }^{(2-3,5)}$.

The nursing professional has the risk of suffering health problems resulting from their daily activities, since their work requires intense physical and psychological demands due to the complexity of the procedures performed, causing severe impacts on their health and quality of life, in addition to interfering with the organizational dynamics of the service and patient safety ${ }^{(6)}$. A systematic review study showed that the prevalence of musculoskeletal disorders reported by nurses in the last 12 months ranged from 33\% to $88 \%$. Such disorders were directly related to their work practice such as elevation, transfer and repositioning of patients, prolonged stay in unsuitable postures for performing procedures, among others ${ }^{(7)}$.

Associated with this, the mental suffering of these professionals also represents a source of illness, which is directly reflected in their work performance. A systematic metaanalysis review to determine the prevalence of depression among nurses working in a hospital setting in Iran over 20 years covering the period 1997-2017 showed a high rate among 4,062 professionals $(26.9 \%)^{(8)}$.

In this sense, the importance of the relationship between the work context and its influence on workers' health has been highlighted in scientific production through the development of research conducted in the last decade, especially in the international context ${ }^{(3,9-12)}$. However, studies addressing this issue in Brazil are still incipient, in which most investigations are restricted to the Southeast region of the country ${ }^{(13-14)}$. Given the above, highlighting this reality may contribute to identifying disease processes, implementing early interventions and improving worker health programs, thus enabling the well-being of nursing professionals.

Thus, this study aims to evaluate the impact of work on the health of nursing professionals.

\section{METHOD}

\section{Study DESIGN}

This is a cross-sectional study with a quantitative approach.

\section{SCENARIO}

This study was performed at a university hospital located in João Pessoa, Paraíba, Brazil.

\section{Population}

The population consisted of all nurses working in the referred hospital. The sample calculation was based on the number of professionals with undergraduate Nursing diplomas registered in the National Register of Health Facilities of the Unified Health System ${ }^{(15)}$ and who had a single active formal work contract with the hospital, totaling 252 nurses. The data were provided by the Institution's Process Management and Information Technology Sector.

Inclusion criteria were defined as having an active employment relationship with the hospital and being a nurse in this service for at least six months. Exclusion criteria were defined as being on vacation, sick leave or maternity leave during data collection.

\section{SAMPLE DEFINITION}

The sample size was defined using the finite population calculation with known proportions, based on a $5 \%$ error margin $($ Error $=0.05)$ with a $95 \%$ confidence interval $(\alpha=$ 0.05 , providing $\left.Z_{0.05 / 2}=1.96\right)$ and considering the proportion of participants of $50 \%(\mathrm{p}=0.5)$, totaling 152 nurses.

\section{DATA COLLECTION}

Data collection was performed between October and November 2017 through individual interviews. Contact with the nurses initially took place at the hospital during their shift periods or upon the professionals' entrance and exit to the workplace in order to provide guidance on the research objectives, request participation in the study and schedule the meeting to complete the self-applicable instruments, respecting the individual availability of each professional.

Data were collected from an instrument to obtain sociodemographic data containing the variables of gender, age, marital status, religion, personal income and family arrangement; health conditions and the Pleasure and Suffering Indicators at Work Scale (PSIWS) ${ }^{(16)}$. The PSIWS consists of 32 questions with Likert-type answer options ranging from 0 (no time) to 6 (six or more times), which assess the occurrence of pleasure and suffering indicators in the last six months of work, covering four Factors: Freedom of Expression, Professional Achievement, Professional Exhaustion, and Lack of Recognition ${ }^{(16)}$.

\section{DATA ANALYSIS AND PROCESSING}

The analysis was performed from the mean among the PSIWS items, being classified in three different levels. The 
indicators for the factors which assess work pleasure (items 1 to 17 ) are classified as positive, satisfactory (score $\geq 4.0$ ); moderate or critical (scores between 3.9 and 2.1); rarely, severe (score $\leq 2.0$ ). The indicators for the factors which evaluate suffering in the workplace (items 18 to 32) are classified as: more negative evaluation, severe $\geq 4$; moderate or critical evaluation between 3.9 and 2.1; less negative evaluation, satisfactory $\leq 2.0^{(16)}$.

The Kolmogorov-Smirnov test was used to verify the normality/symmetry of the numerical data. The maximum significance level used for statistical analysis was $5 \%(p \leq 0.05)$. The reliability of the factors was assessed by estimating the internal consistency using Cronbach's alpha coefficient. The Mann-Whitney and Kruskal-Wallis tests were used to associate the variables.

\section{ETHICAL ASPECTS}

The study was developed according to the recommendations of Resolution no. 466/2012 of the National Health Council, being approved by the Research Ethics Committee of Lauro Wanderley University Hospital under opinion no. 2.259.018, of September 4,2017. The participants were duly informed about the justification of the research, its purpose, risks and benefits, procedures to be performed, guarantee of confidentiality of the information provided and they signed the Free and Informed Consent Form.

\section{RESULTS}

There were 152 nurses who participated in this study, without any sample loss. There was a higher prevalence of females (91.4\%), aged between 30 and 39 years (48.0\%) and average age of 39.3 years (SD \pm 0.963$)$, married or in a stable union (62.5\%), practitioners of some religion (98.7\%), with personal monthly income between $\mathrm{R} \$ 5,000$ and $\mathrm{R} \$ 7,999$ (65.1\%), and who live with one to two people (42.8\%).

When assessing nursing work activity, it is observed that the Pleasure indicator and its domains were classified as satisfactory, while the Suffering Factors obtained a critical evaluation. The scale showed good internal reliability, with most Cronbach's Alpha values higher than 0.80 (Table 1).

Statistically significant associations $(p \leq 0.05)$ between pleasure and suffering at work were evidenced with the health status, physical activity, smoking and alcohol consumption variables (Table 2 ).

Table 1 - Evaluation of pleasure and suffering indicators in nursing work - João Pessoa, PB, Brazil, 2017.

\begin{tabular}{|c|c|c|c|c|c|}
\hline Indicator & Factor & Mean & $\begin{array}{l}\text { Standard } \\
\text { deviation }\end{array}$ & Evaluation & Cronbach's alpha \\
\hline \multirow{2}{*}{ Pleasure } & Professional Achievement & 4.2 & 1.326 & Satisfactory & 0.81 \\
\hline & Freedom of Expression & 4.1 & 1.315 & Satisfactory & 0.79 \\
\hline \multirow{2}{*}{ Suffering } & Professional Exhaustion & 2.9 & 1.559 & Critical & 0.86 \\
\hline & Lack of Recognition & 2.1 & 1.525 & Critical & 0.87 \\
\hline
\end{tabular}

Table 2 - Association between health conditions and indicators of pleasure and suffering in nursing work - João Pessoa, PB, Brazil, 2017.

\begin{tabular}{|c|c|c|c|c|c|c|}
\hline \multirow[b]{2}{*}{ Variables } & \multicolumn{3}{|c|}{ Pleasure } & \multicolumn{3}{|c|}{ Suffering } \\
\hline & Mean & $\begin{array}{l}\text { Standard } \\
\text { deviation }\end{array}$ & P-value & Mean & $\begin{array}{l}\text { Standard } \\
\text { deviation }\end{array}$ & P-value \\
\hline \multicolumn{7}{|c|}{ Health situation } \\
\hline Excellent & 4.6 & 0.806 & $0.002^{* *}$ & 1.9 & 1.332 & $0.001^{* *}$ \\
\hline Good & 4.3 & 1.217 & & 2.2 & 1.479 & \\
\hline Normal & 3.8 & 1.156 & & 3.2 & 1.263 & \\
\hline Bad & 3.1 & 1.382 & & 3.3 & 0.943 & \\
\hline \multicolumn{7}{|c|}{ Physical activity } \\
\hline Yes & 4.5 & 1.077 & $<0.001^{*}$ & 2.1 & 1.459 & $0.002 *$ \\
\hline No & 3.8 & 1.241 & & 2.8 & 1.356 & \\
\hline \multicolumn{7}{|l|}{ Smoking } \\
\hline No & 4.2 & 1.169 & $0.005^{*}$ & 2.4 & 1.452 & $0.042 *$ \\
\hline Yes & 3.1 & 1.200 & & 3.2 & 1.209 & \\
\hline \multicolumn{7}{|c|}{ Consumption alcoholic beverages } \\
\hline No & 4.4 & 1.095 & $0.003^{*}$ & 2.1 & 1.427 & $0.001 *$ \\
\hline Yes & 3.8 & 1.267 & & 2.9 & 1.356 & \\
\hline
\end{tabular}

Statistically significant associations $(\mathrm{p} \leq 0.05)$ were identified between pleasure and suffering indicators at work with the presence of disease or health problem, highlighting diseases of the musculoskeletal system and connective tissue and mental and behavioral disorders. The daily use of medications, including analgesics and anti-inflammatory drugs, also showed a statistically significant association $(p \leq 0.05)$ with pleasure and suffering indicators at work (Table 3). 
Table 3 - Association of health problems and medication use with pleasure and suffering indicators in nursing work - João Pessoa, PB, Brazil, 2017.

\begin{tabular}{|c|c|c|c|c|c|c|}
\hline \multirow[b]{2}{*}{ Variables } & \multicolumn{3}{|c|}{ Pleasure } & \multicolumn{3}{|c|}{ Suffering } \\
\hline & Mean & $\begin{array}{l}\text { Standard } \\
\text { deviation }\end{array}$ & P-value* & Mean & $\begin{array}{l}\text { Standard } \\
\text { deviation }\end{array}$ & P-value \\
\hline \multicolumn{7}{|c|}{ Presence of illness or health problem } \\
\hline No & 4.5 & 1.014 & 0.003 & 2.2 & 1.480 & 0.072 \\
\hline Yes & 3.9 & 1.255 & & 2.6 & 1.418 & \\
\hline \multicolumn{7}{|c|}{ Health problems } \\
\hline \multicolumn{7}{|c|}{ Osteomuscular and connective tissue diseases } \\
\hline No & 4.5 & 1.097 & $<0.001$ & 2.2 & 1.437 & 0.002 \\
\hline Yes & 3.5 & 1.155 & & 2.9 & 1.364 & \\
\hline \multicolumn{7}{|c|}{ Mental and behavioral disorders } \\
\hline No & 4.2 & 1.192 & 0.011 & 2.4 & 1.442 & 0.057 \\
\hline Yes & 3.4 & 1.096 & & 3.1 & 1.409 & \\
\hline \multicolumn{7}{|c|}{ Daily use of medication } \\
\hline No & 4.6 & 0.912 & 0.001 & 2.3 & 1.396 & 0.162 \\
\hline Yes & 3.8 & 1.321 & & 2.6 & 1.488 & \\
\hline \multicolumn{7}{|l|}{ Drug class } \\
\hline \multicolumn{7}{|l|}{ Analgesic } \\
\hline No & 4.4 & 1.100 & $<0.001$ & 2.3 & 1.441 & 0.025 \\
\hline Yes & 3.6 & 1.249 & & 2.8 & 1.417 & \\
\hline \multicolumn{7}{|c|}{ Anti-inflammatory } \\
\hline No & 4.5 & 1.080 & $<0.001$ & 2.1 & 1.417 & $<0.001$ \\
\hline Yes & 3.4 & 1.191 & & 3.2 & 1.208 & \\
\hline \multicolumn{7}{|c|}{ Nervous system medications } \\
\hline Yes & 3.2 & 1.232 & 0.001 & 3.1 & 1.358 & 0.046 \\
\hline No & 4.3 & 1.151 & & 2.4 & 1.445 & \\
\hline
\end{tabular}

* Mann-Whitney test.

\section{DISCUSSION}

The pleasure at work indicators presented satisfactory averages, while the suffering factors exhibited critical levels. This finding may be a reflection of the current professional market in health, where there is a decrease in the humanization of interpersonal relationships and in which the worker is only perceived as a workforce to meet the needs of the organization, resulting in illness in the professional and being on leave from work ${ }^{(9)}$.

Given this scenario, it is clear that the organizational process of work and the social space in which it is developed impact socio-professional interactions, increasing the individual's vulnerability, or in other cases promoting positive coping with the obstacles experienced ${ }^{(17)}$. Thus, individuals get sick when they do not have the capacity to satisfactorily cope with the impositions and pressures in the workplace, since the needs of the organization stand out to the detriment of the professional's interests ${ }^{(13,17)}$.

The work context is not limited to the physical or social space in which the activities are developed, but also includes interpersonal relationships, workers' perception of the relevance of their function, service dynamics, organizational support, environment characteristics and resource availability, generating multiple disruptions to the health of the professional ${ }^{(16)}$.

In this sense, pleasure experiences as a result of the interrelationship between professional achievement and freedom of expression involve aspects such as well-being, satisfaction, motivation, recognition and pride in the performed activities, opportunities to express feelings and opinions to colleagues, and bosses, the presence of trust, solidarity and cooperation among workers, as well as the opportunity to use creativity in the workplace ${ }^{(16)}$.

In evaluating suffering at work, its assessment addresses the workers' perception of the negative experiences present during their activities such as emotional exhaustion, stress, dissatisfaction, overload, frustration and insecurity, in addition to feelings of devaluation, indignation, worthlessness, disqualification, injustice, discrimination and lack of recognition ${ }^{(16)}$.

Nursing practice is often permeated by occupational risks, especially in a hospital environment, due to the complexity of the care provided and the level of responsibility required of each professional. Thus, the high demand for work can cause damage to the mental health of nurses, causing physical consequences such as intense fatigue, migraine, anxiety attacks, depressive episodes, and Burnout Syndrome, among others, which result in daily experiences of suffering and can negatively affect the quality of life of these professionals ${ }^{(3-4)}$.

The association between health status and indicators of pleasure and suffering at work was statistically significant, with the most frequent positive experiences among individuals who reported their health as excellent or good. In contrast, negative experiences were more prevalent among nurses who perceived their health as average or poor. Nursing professionals are a vulnerable population for developing health problems which are related to the organizational aspects of daily practice, in which an intense and stressful work routine with frequent exposure to occupational risks prevails ${ }^{(9,18)}$.

The practice of physical activity was also statistically significant when associated with pleasure and suffering indicators, in which negative experiences were more present 
among nurses who did not perform such activity. Although maintaining a healthy lifestyle is extremely important for health promotion and to prevent diseases and disabilities, nurses have difficulties maintaining regular practice of physical activity, mainly due to the intense work routine with day and night shifts which make it difficult to organize time, and represent a risk to the health of these professionals ${ }^{(10)}$.

In this sense, introducing programs aimed at improving workers' health, encouraging physical activity and adherence to healthy eating can provide numerous benefits for professionals and the institution, such as greater willingness to work, more satisfaction with their performed activities and recognition of the company's concern with the well-being of its employees ${ }^{(19)}$. A study with 75 employees in a medium-sized company in Germany found that promoting health through physical activity in the workplace had positive effects on quality of life and working capacity, thus resulting in mutual benefit for those involved ${ }^{(11)}$.

The smoking variable was associated with the pleasure and suffering indicators in work practice, which corroborates a study with 309 nursing team professionals in the city of Jequié, Bahia state, Brazil, which found a positive association between smoking and dissatisfaction with the quality of life at work ${ }^{(20)}$. This finding could be justified by the use of tobacco as a strategy to reduce or control anxiety levels, given that nurses' work can become stressful due to the high demand for responsibility and frequent coexistence with human suffering ${ }^{(21)}$.

A statistically significant association with the evaluated indicators was also evidenced regarding the consumption of alcoholic beverages, and the highest means of suffering factors at work were evidenced by nurses who consumed alcohol, which could be related to the effects on the body, negatively interfering in the performance of their practices.

Frequent alcohol ingestion causes various changes in the body, which progress according to the amount consumed. The cardiovascular and digestive systems are the most affected, generating effects such as increased heart rate and blood pressure immediately after ingestion, as well as impaired digestion and hepatic metabolism, and increased risk of myocardial infarction ${ }^{(22)}$.

This substance is also widely used to reduce stress as it quickly causes physical and mental relaxation, and is often ingested by the general population and health professionals ${ }^{(12,23)}$. A study of nurses in Colombia identified a high prevalence of alcohol consumption, in which its use could be related to the existence of organizational problems and conflicts among the team, which resulted in alcohol consumption as a defense mechanism for stress reduction ${ }^{(12)}$.

Nurses who did not have illnesses or health problems showed a significant association with pleasure indicators at work, showing higher averages of positive experiences in the workplace environment. Musculoskeletal system and connective tissue diseases as well as mental and behavioral disorders were statistically significant with the analyzed indicators, since nurses who did not have such conditions had higher levels of pleasure, while professionals who presented such disorders/diseases suffered more in the workplace.
Musculoskeletal and connective tissue problems are frequent in nursing professionals resulting from physical exhaustion and stress due to the excessive effort required to perform their activities and the demands related to the nurse position. Such problems generate suffering in professionals and compromise the performance of their functions ${ }^{(4)}$.

Overweight and obesity are also problems which can trigger musculoskeletal disorders or aggravate their symptoms. They are referred to in the literature as important risk factors for circulatory system diseases such as hypertension and varicose veins in the lower limbs, as well as endocrine problems, especially diabetes mellitus ${ }^{(24)}$.

A study conducted in England showed that a quarter of nurses in the country were obese ${ }^{(24)}$. The prevalence was even higher in Scotland with $69.1 \%$ of nurses being overweight or obese ${ }^{(25)}$. The implications of being overweight are not restricted to the individual sphere, but also interfere with the care provided and adherence of patients to health recommendations. A systematic review identified that personal behaviors influence health promotion practice, as patients are more likely to accept health advice from visibly healthy professionals ${ }^{(26)}$.

Mental and behavioral disorders were another health condition which showed a significant association with the pleasure and suffering indicators at work in nurses, which could be justified by the fact that such problems interfere with work practice and the perception of professionals regarding the quality of care provided ${ }^{(27)}$.

The onset of symptoms of anxiety, irritability, anguish, tension and psycho-emotional changes cause intense suffering in nurses, being related to the high psychological demands required by work and reduced rest time. These generate a high rate of absenteeism due to sick leave, cause difficulties in interpersonal relationships with other professionals and cause damage to patient safety as such problems are associated with a large number of adverse events ${ }^{(4)}$.

The daily use of some drugs such as analgesics, anti-inflammatory drugs and drugs which act on the nervous system showed a significant association with the pleasure and suffering indicators in nursing work. The constant use of medicines denotes the presence of health problems which may interfere with developing the daily activities of the investigated professionals, experiencing negative feelings related to work practice.

The exacerbated use of medicines by these professionals is a problem which has repercussions on their health, especially self-medication, since it can interfere with the early diagnosis of health problems by omitting the onset of symptoms, making it difficult to seek treatment, worsening the presented condition and cause chemical dependence ${ }^{(28)}$.

Self-medication is common among health professionals, especially nurses, since they have knowledge about the characteristics of each drug and their respective therapeutic indications, which would exempt them from consultation with a doctor to prescribe these drugs ${ }^{(29)}$. In this sense, the use of analgesics and anti-inflammatories could be related to the high number of nurses who have musculoskeletal problems in the present study, and use these drugs in search for immediate pain relief when episodes occur in the workplace ${ }^{(4)}$. 
Nursing working conditions may increase the vulnerability of professionals to physical and mental illness, as they are exposed to unhealthy working environments with high workload, work overload and constant living with human suffering, which represents a risk for developing various occupational diseases ${ }^{(9,30)}$.

Mental and behavioral disorders could justify the use of drugs which act on the nervous system and their association with suffering indicators at work, since the activities performed by nurses require high psychological load and high concentration power, often exceeding the capacity of the individual, which then causes illness in the worker ${ }^{(25)}$. Thus, the use of these drugs occurs as a defense or protection strategy for professionals who seek to perform their duties satisfactorily and also to reduce the stress caused by work ${ }^{(28)}$.

\section{CONCLUSION}

The results of the present study demonstrate that nurses' work had a negative impact on the health of these professionals, exhibiting critical levels of suffering. In addition, some individual characteristics of these workers also influenced the development of their work activities, such as regular physical activity, tobacco use and alcohol consumption.

In this sense, the need for health services to implement strategies to promote workers' health is emphasized, seeking to prevent accidents, reduce occupational risks and adopt healthy lifestyle habits. It is also appropriate to highlight the importance of recognizing the work of nursing professionals, ensuring them professional autonomy, training, scientific updates and healthy and humanized management practices which contribute to the satisfaction of these professionals.

The limitations of this study were related to the use of a cross-sectional methodology, making it impossible to examine causal relationships. Therefore, further studies are suggested to investigate the impact of interventions on nurses' work, as well as longitudinal studies which enable making conclusions about the cause and effect relationship.

\section{RESUMO}

Objetivo: Avaliar o impacto do trabalho para a saúde do profissional de enfermagem. Método: Trata-se de um estudo transversal e quantitativo, realizado com enfermeiros de um hospital universitário em João Pessoa, Paraíba, Brasil. Os dados foram coletados por meio de entrevistas, com uso de um instrumento para obtenção dos dados sociodemográficos e condições de saúde e da Escala de Indicadores de Prazer e Sofrimento no Trabalho. Resultados: Participaram 152 enfermeiros. A Vivência de Prazer e os seus domínios foram classificados como satisfatórios, enquanto os Fatores de Sofrimento e seus domínios obtiveram avaliação crítica. Foram observadas associações estatisticamente significativas $(\mathrm{p} \leq 0,05)$ entre os indicadores de prazer e sofrimento e algumas condições de saúde, problemas de saúde e uso de medicamentos. Conclusão: Os níveis satisfatórios de prazer apresentaram associação com melhores condições de saúde e níveis críticos de sofrimento foram associados a piores condições de saúde.

\section{DESCRITORES}

Trabalho; Enfermagem; Satisfação no Emprego; Saúde do Trabalhador.

\section{RESUMEN}

Objetivo: Evaluar el impacto del trabajo en la salud del profesional enfermero. Método: Se trata de un estudio transversal y cuantitativo, llevado a cabo con enfermeros de un hospital universitario en João Pessoa, Paraíba, Brasil. Los datos fueron recogidos mediante entrevistas, empleándose un instrumento para la obtención de los datos sociodemográficos y las condiciones de salud y de la Escala de Indicadores de Placer y Sufrimiento en el Trabajo. Resultados: Participaron 152 enfermeros. La Vivencia de Placer y sus dominios fueron clasificados como satisfactorios, mientras que los Factores de Sufrimiento y sus dominios obtuvieron evaluación crítica. Fueron observadas asociaciones estadísticamente significativas $(p \leq 0,05)$ entre los indicadores de placer y sufrimiento y algunas condiciones de salud, problemas de salud y uso de fármacos. Conclusión: Los niveles satisfactorios de placer presentaron asociación con mejores condiciones de salud, y niveles críticos de sufrimiento estuvieron asociados con peores condiciones de salud.

\section{DESCRIPTORES}

Trabajo; Enfermería; Satisfacción en el Trabajo; Salud Laboral.

\section{REFERENCES}

1. Paolini KS. Desafios da inclusão do idoso no mercado de trabalho. Rev Bras Med Trab. 2016;14(2):177-82. DOI: http://dx.doi.org/10.5327/ Z1679-443520162915

2. Silva VR, Velasque LS, Tonini T. Job satisfaction in an oncology nursing team. Rev Bras Enferm. 2017;70(5):1040-7. DOI: http://dx.doi. org/10.1590/0034-7167-2016-0422

3. Suliman M, Aljezawi M. Nurses' work environment: indicators of satisfaction. J Nurs Manag. 2018;26(5):525-30. DOI: http://dx.doi. org/10.1111/jonm.12577

4. Guimarães ALO, Felli VEA. Notification of health problems among nursing workers in university hospitals. Rev Bras Enferm. 2016;69(3):47582. DOI: http://dx.doi.org/10.1590/0034-7167.2016690313i

5. Souza EA, Teixeira CF, Souza MKB. Análise da produção científica nacional sobre o trabalho da enfermeira (1988-2014). Saúde Debate. 2017;41(113):630-46. DOI: http://dx.doi.org/10.1590/0103-1104201711322

6. Marques DO, Pereira MS, Souza ACS, Vila VSC, Almeida CCOF, Oliveira EC. Absenteeism: illness of the nursing staff of a university hospital. Rev Bras Enferm. 2015;68(5):594-600. DOI: http://dx.doi.org/10.1590/0034-7167.2015680516i

7. Soylar P, Ozer A. Evaluation of the prevalence of musculoskeletal disorders in nurses: a systematic review. Med Sci. 2018;7:479-85. DOI: http://dx.doi.org/10.5455/medscience.2017.06.8747

8. Fereidouni Z, Dehghan A, Kalyani MN. The prevalence of depression among nurses in Iran: a systematic review and meta-analysis. Int J Med Rev. 2018;5(4):163-7. DOI: http://dx.doi.org/10.29252/IJMR-050407 
9. Alilu L, Zamanzadeh V, Valizadeh L, Habibzadeh H, Gillespie M. A grounded theory study of the intention of nurses to leave the profession. Rev Latino Am Enfermagem [Internet]. 2017 [cited 2018 July 15];25:e2894. Available from: https://www.ncbi.nlm.nih.gov/ pmc/articles/PMC5479374/

10. Yao Y, Zhao S, An Z, Wang S, Li H, Lu L, et al. The associations of work style and physical exercise with the risk of work-related musculoskeletal disorders in nurses. Int J Occup Med Environ Health. 2019;32(1):15-24. DOI: http://dx.doi.org/10.13075/ijomeh.1896.01331

11. Biallas B, Froböse I, Zöller M, Wilke C. Analysis of workplace health promotion and its effect on work ability and health-related quality of life in a medium-sized business. Gesundheitswesen. 2015;77(5):357-61. DOI: http://dx.doi.org/10.1055/s-0034-1372625

12. Londoño Restrepo J, Chica Álvarez OP, Marin Agudelo IC. Riesgo de depresión, alcoholismo, tabaquismo y consumo de sustancias psicoactivas en personal de enfermería, de dos instituciones hospitalarias del área metropolitana de la ciudad de Medellín. Med UPB [Internet]. 2017 [citado 2018 jul. 10];36(1):34-43. Disponible en: https://revistas.upb.edu.co/index.php/Medicina/article/view/7486/6834

13. Dorigan GH, Guirardello EB. Nursing practice environment, satisfaction and safety climate: the nurses' perception. Acta Paul Enferm. 2017;30(1):129-35. DOI: http://dx.doi.org/10.1590/1982-0194201700021

14. Santos JLG, Menegon FHA, Pin SB, Erdmann AL, Oliveira RJT, Costa IAP. The nurse's work environment in a hospital emergency service. Rev Rene. 2017;18(2):195-203. DOI: http://dx.doi.org/10.15253/2175-6783.2017000200008

15. Brasil. Ministério da Saúde. DATASUS. Cadastro Nacional de Estabelecimentos de Saúde [Internet]. Brasília; 2017 [citado 2018 jun. 12 ]. Disponível em: http://cnes.datasus.gov.br/pages/consultas.jsp

16. Mendes AM. Psicodinâmica do trabalho: teoria, método e pesquisas. São Paulo: Casa do Psicólogo; 2007.

17. Maissiat GS, Lautert L, Dal Pai D, Tavares JP. Work context, job satisfaction and suffering in primary health care. Rev Gaúcha Enferm. 2015;36(2):42-9. DOI: http://dx.doi.org/10.1590/1983-1447.2015.02.51128

18. Santana LL, Sarquis LMM, Brey C, Miranda FMD, Felli VEA. Absenteeism due to mental disorders in health professionals at a hospital in southern Brazil. Rev Gaúcha Enferm. 2016;37(1):e53485. DOI: http://dx.doi.org/10.1590/1983-1447.2016.01.53485

19. Hipólito MCV, Masson VA, Monteiro MI, Gutierrez GL. Quality of working life: assessment of intervention studies. Rev Bras Enferm. 2017;70(1):178-86. DOI: http://dx.doi.org/10.1590/0034-7167-2015-0069

20. Azevedo BDS, Nery AA, Cardoso JP. Occupational stress and dissatisfaction with quality of work life in nursing. Texto Contexto Enferm. 2017;26(1):e3940015. DOI: http://dx.doi.org/10.1590/0104-07072017003940015

21. Carceller-Maicas N, Ariste S, Martínez-Hernáez A, Martorell-Poveda MA, Correa-M, DiGiacomo SM. El consumo de tabaco como automedicación de depresión/ansiedad entre los jóvenes: resultados de un estudio con método mixto. Adicciones. 2014;26(1):34-45. DOI: https://doi.org/10.20882/adicciones.127

22. Connor JP, Haber PS, Hall WD. Alcohol use disorders. Lancet. 2016;387(10022):988-98. DOI: https://doi.org/10.1016/S01406736(15)00122-1

23. Tobias JSP, Silva DLF, Ferreira PAM, Silva AAM, Ribeiro RS, Ferreira ASP. Alcohol use and associated factors among physicians and nurses in northeast Brazil. Alcohol. 2019;75:105-12. DOI: https://doi.org/10.1016/j.alcohol.2018.07.002

24. Kyle RG, Wills J, Mahoney C, Hoyle L, Kelly M, Atherton IM. Obesity prevalence among healthcare professionals in England: a crosssectional study using the Health Survey for England. BMJ Open [Internet]. 2017 [cited 2018 May 25];7(12):e018498. Available from: https://www.ncbi.nlm.nih.gov/pmc/articles/PMC5719305/

25. Kyle RG, Neall RA, Atherton IM. Prevalence of overweight and obesity among nurses in Scotland: a cross-sectional study using the Scottish Health Survey. Int J Nurs Stud. 2016;53:126-33. DOI: http://dx.doi.org/10.1016/j.ijnurstu.2015.10.015

26. Kelly M, Wills J, Sykes S. Do nurses' personal health behaviours impact on their health promotion practice? A systematic review. Int J Nurs Stud. 2017;76:62-77. DOI: http://dx.doi.org/10.1016/j.ijnurstu.2017.08.008

27. Maciel MPGS, Santana FL, Martins CMA, Costa WT, Fernandes LS, Lima JS. Use of psychoactive medication between health professionals. J Nurs UFPE on line [Internet]. 2017 [cited 2018 June 15];11 Suppl 7:2881-7. Available from: https://periodicos.ufpe.br/revistas/ revistaenfermagem/article/view/10177

28. Cares A, Pace E, Denious J, Crane LA. Substance use and mental illness among nurses: workplace warning signs and barriers to seeking assistance. Subst Abus. 2015;36(1):59-66. DOI: https://doi.org/10.1080/08897077.2014.933725

29. Ross CA, Jakubec SL. Berry NS, Smye V. "A two glass of wine shift": dominant discourses and the social organization of nurses'substance use. Glob Qual Nurs Res. 2018;5:2333393618810655. DOI: https://doi.org/10.1177/2333393618810655

30. Prestes FC, Beck CLC, Magnago TSBS, Silva RM. Pleasure-suffering indicators of nursing work in a hemodialysis nursing service. Rev EsC Enferm USP. 2015;49(3):465-72. DOI: https://doi.org/10.1590/S0080-623420150000300015 